\title{
The Relationship between Sanitation and Diarrhea in Kabupaten Pidie, Aceh (Used Validity Inference)
}

\section{Yeggi Darnas ${ }^{1}$ and Riska Yolanda ${ }^{2}$}

${ }^{1}$ Islamic State University of Ar-Raniry, Departement Sains and Technology, Jl. Syeikh Abdul Rauf, Kopelma-Darussalam, Banda Aceh, Indonesia

${ }^{2}$ Postgraduate Student Faculty of Public Health, Universitas Indonesia, Depok, Indonesia

\section{Abstract}

According to World Health Organization (WHO), the world most prevalent issues are illness and death caused by environmental factors such as water, land, and air. The causes contribute to premature death of millions of people, especially infants and children every year. This issue mostly experienced by developing country, including Indonesia, approximately four million infants and children die from diarrhea due to

Corresponding Author:

Yeggi Darnas

darnasjunior@ar-raniry.ac.id

Received: 26 December 2018

Accepted: 23 February 2019

Published: 7 March 2019

Publishing services provided by

Knowledge E

(c) Yeggi Darnas and Riska

Yolanda. This article is

distributed under the terms of

the Creative Commons

Attribution License, which

permits unrestricted use and

redistribution provided that the

original author and source are

credited.

Selection and Peer-review under the responsibility of the $2 \mathrm{nd}$ International Meeting of Public Health 2016 Conference Committee.

\section{G OPEN ACCESS} contaminated water and food. Unavailability of solid waste management and domestic wastewater service in the region causes poor sanitation, it results in the high incidence of contaminated water. This study would analyze the relationship between sanitation and diarrhea in Kabupaten Pidie, Aceh using validity inference. Validity refers to the approximate truth of an inference. Valid meant the extent to which relevant evidence supports that inference as bring true or correct. Usually, that evidence comes from both empirical findings and the consistency of these findings with other sources of knowledge, including past finding and theories. Assessing validity always entails fallible human judgments. Validity is not absolute; various degrees of validity can be invoked. In this study from table distribution $\mathrm{F}$, we got $\mathrm{F}$ table 3.95 with probability $\alpha(5 \%)$, df-numerator $[(k-1)=1]$ and df-denominator $[k(N-1)=90]$ and $F$ arithmetic is 5.95269E-09. It means F arithmetic $<\mathrm{F}$ table so that, Hypothesis null $(\mathrm{Ho})$ accepted and sanitation have significant effect on diarrhea.

Keywords: Diarrhea; inference; Kabupaten Pidie; sanitation; validity

\section{Introduction}

The Indonesia Ministry of Health uses the infant, child, and maternal mortality rate, also morbidity figures of some diseases to asses the health degree. The degree of health status is influenced by several factors, including health factors, availability of health infrastructure, economic, education, social environment, heredity, and sanitation that is always forgotten by the Indonesian goverment. 
If a city or village does not have good sanitation system, the environment will be polluted and public health will be disturbed so that the disease will be coming. The poor sanitation condition will potentially lead to increasing cases ofdiarrhea, malaria, dengue fever, and filariasis. In this study, the author will discuss the relationship between sanitation and diarrhea, because diarrhea is the direct impact of poor sanitary condition while malaria, dengue fever and filariasis indirect cause of poor sanitation which are mediated by mosquitos as the vector disease.

Diarrhea is endemic. The potential disease outbreak of diarrhea is often accompanied by death.. The cause of diarrhea in the community is the poor health behavior, poor waste management, and contaminated drinking water. There were 201,671 of diarrhea patient's cases in Aceh and only 89,447 patients that were treated. There were only $44.25 \%$ of this incidence that could be treated by Dinas Kesehatan Provinsi Aceh in 2015.

Kabupaten Pidie through sanitation working group began thinking to improve sanitation plan, develop, implementation, supervise and monitor the future development of sanitation. The government of Pidie realized that sanitation infrastructure was poor, indicated by the high incidence of diarrhea in Pidie by the third number after Northern Aceh and Bieuren based on Aceh health profile. The current domestic wastewater coverage in Pidie can be seen in Table 1 while the risked area and sanitation problems can be seen in Figure 1 (PPSP 2015).

\section{Methods}

Validity refers to the approximate truth of an inference. Valid is the extentto which relevant evidence supports that inference as bring true or correct. Usually, that evidence comes from both empirical findings and the consistency of these findings with other sources of knowledge, including past finding and theories. Assessing validity always entails fallible human judgments. Validity is not absolute; various degrees of validity can be invoked. As a result, when we use prefaced by approximant or tentatively (Shadish et al. 2002).

In this study, validity inference was assessed using Null Hypothesis (Ho) and the Alternative Hypothesis $(\mathrm{H} 1)$ with $\mathrm{F}$ test. $\mathrm{F}$ test know as test model/Anova test, that test to see how of independent variables $(x)$ the influence the dependent variables $(y)$, or to test the regression model that we make good and significant or not good and not significant. In this study, we have to of the independent variable, there are Number of families who defecation $\left(x_{1}\right)$ and Number of families who have unsafe latrines $\left(x_{j}\right)$. And the dependent variable is diarrhea (y). $\mathrm{F}$ test can be done by comparing the $\mathrm{F}$ arithmetic 


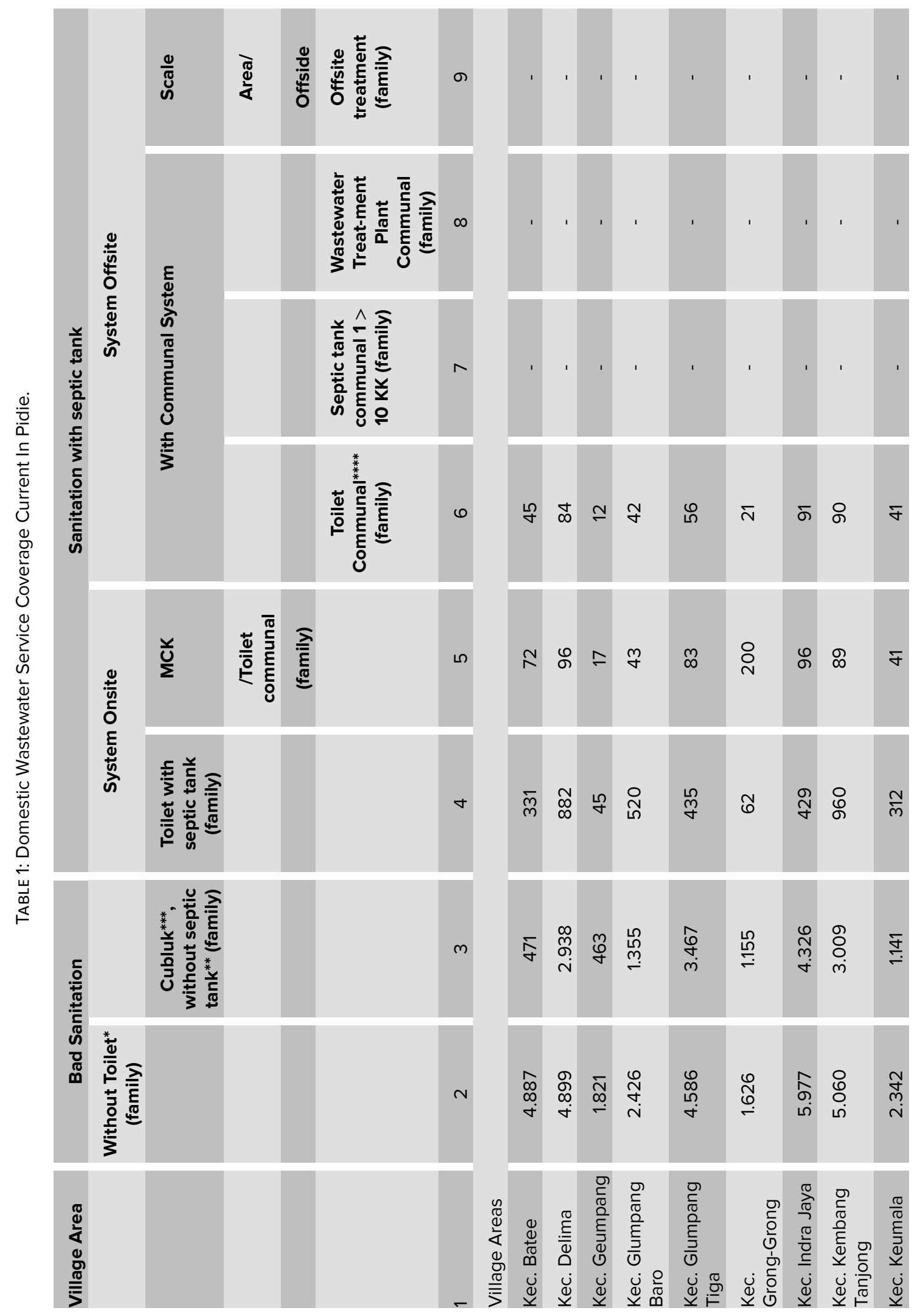




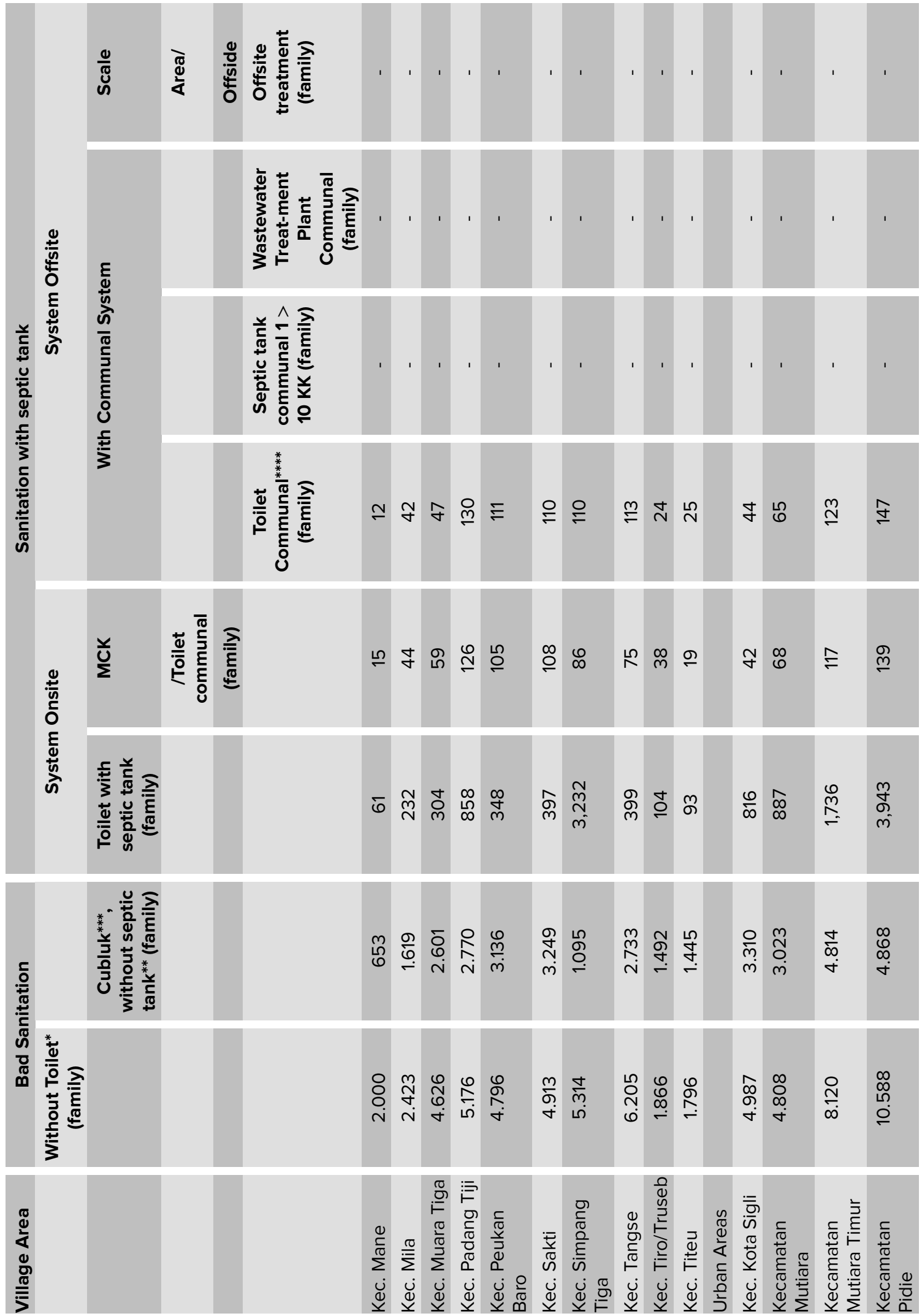




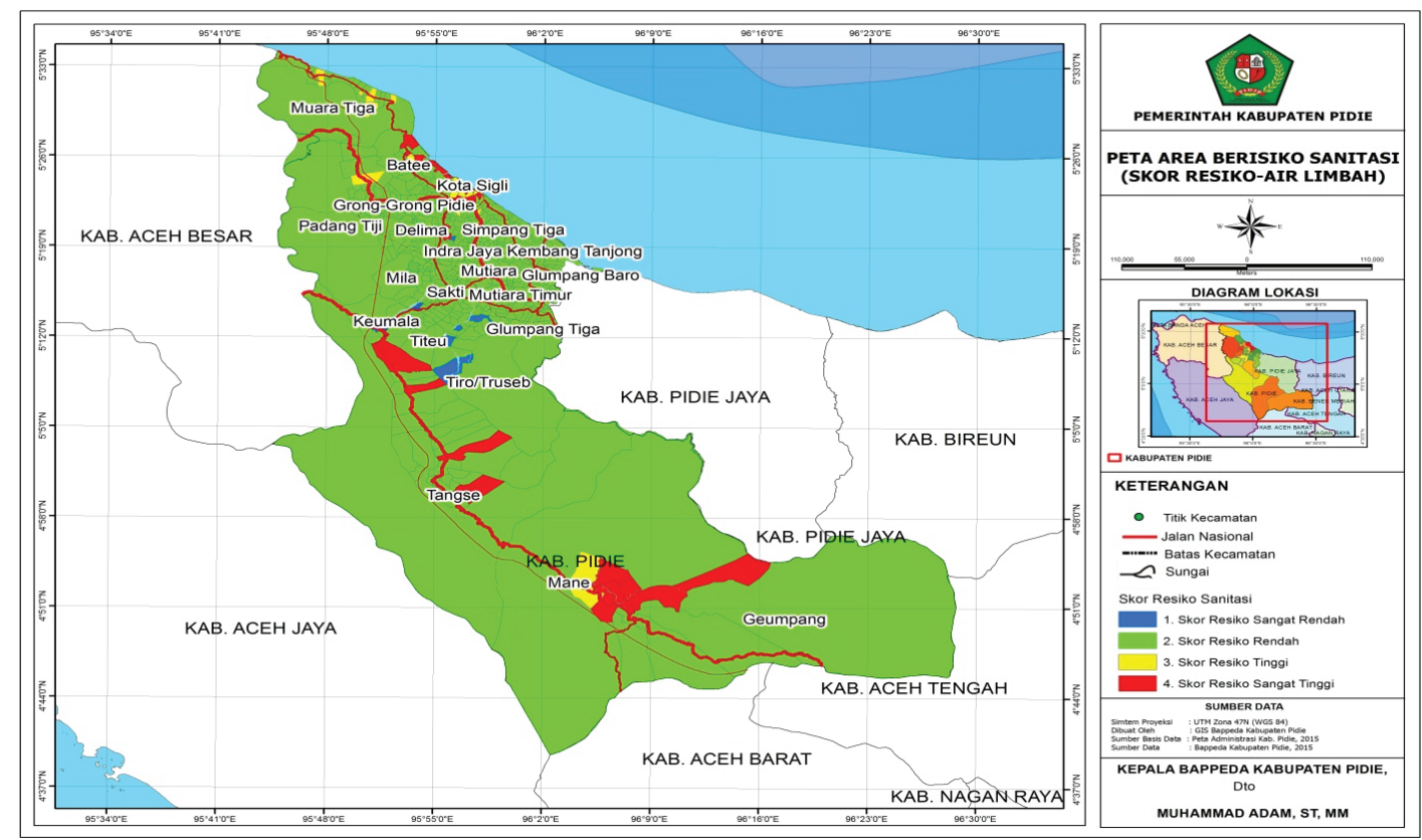

Figure 1: Risk areas and sanitation problems.

with $\mathrm{F}$ table, where if $\mathrm{F}$ arithmetic $>\mathrm{F}$ table (Ho rejected and $\mathrm{H} 1$ accepted) and where if $\mathrm{F}$ arithmetic $<\mathrm{F}$ table (Ho accepted and $\mathrm{H} 1$ rejected).

\section{Results and Discussion}

This study will be used One - Way Anova Method, where Ho is sanitation have a significant effect on diarrhea; $\mathrm{H} 1$ is no significant effect of sanitation on diarrhea and analysis data with confidence level $95 \%$ and $5 \%$ error. The amount data is number of families who defecation $\left(x_{1}\right)$ and the number of families who have unsafe latrines $\left(x_{2}\right)$ on 23 subdistricts in Pidie (number of data 46) and the dependent variable (y) is diarrhea.

TABLE 2: Analysis data.

\begin{tabular}{|c|c|c|c|}
\hline $\begin{array}{l}\text { Number of } \\
\text { families who } \\
\text { defecation }\left(x_{1}\right)\end{array}$ & $\mathbf{x i j}{ }^{2}$ & $\begin{array}{c}\text { Number of } \\
\text { families who } \\
\text { have unsafe } \\
\text { latrines }\left(\mathbf{x}_{j}\right)\end{array}$ & $\mathbf{x i j}^{2}$ \\
\hline 4.887 & 23.882 .769 & 471 & 221841 \\
\hline 4.899 & 24.000 .201 & 2.938 & 8631844 \\
\hline 1.821 & 3.316 .041 & 463 & 214369 \\
\hline 2.426 & 5.885 .476 & 1.355 & 1836025 \\
\hline 4.586 & 21.031.396 & 3.467 & 12020089 \\
\hline 1.626 & 2.643 .876 & 1.155 & 1334025 \\
\hline 5.977 & 35.724 .529 & 4.326 & 18714276 \\
\hline 5.060 & 25.603 .600 & 3.009 & 9054081 \\
\hline
\end{tabular}




\begin{tabular}{|lccc}
$\begin{array}{l}\text { Number of } \\
\text { families who } \\
\text { defecation }\left(\mathbf{x}_{1}\right)\end{array}$ & $\mathbf{x i j}^{2}$ & $\begin{array}{c}\text { Number of } \\
\text { families who } \\
\text { have unsafe } \\
\text { latrines }\left(\mathbf{x}_{j}\right)\end{array}$ & $\mathbf{x i j}^{2}$ \\
\hline 2.342 & 5.484 .964 & 1.141 & 1301881 \\
\hline 2.000 & 4.000 .000 & 653 & 426409 \\
\hline 2.423 & 5.870 .929 & 1.619 & 2621161 \\
\hline 4.626 & 21.399 .876 & 2.601 & 6765201 \\
\hline 5.176 & 26.790 .976 & 2.770 & 7672900 \\
\hline 4.796 & 23.001 .616 & 3.136 & 9834496 \\
\hline 4.913 & 24.137 .569 & 3.249 & 10556001 \\
\hline 5.314 & 28.238 .596 & 1.095 & 1199025 \\
\hline 6.205 & 38.502 .025 & 2.733 & 7469289 \\
\hline 1.866 & 3.481 .956 & 1.492 & 2226064 \\
\hline 1.796 & 3.225 .616 & 1.445 & 2088025 \\
\hline 4.987 & 24.870 .169 & 3.310 & 10956100 \\
\hline 4.808 & 23.116 .864 & 3.023 & 9138529 \\
\hline 8.120 & 65.934 .400 & 4.814 & 23174596 \\
\hline 10.588 & 112.105 .744 & 4.868 & 23697424 \\
\hline 101.242 & 552.249 .188 & 55.133 & 171.153 .651 \\
\hline
\end{tabular}

$$
\begin{gathered}
\text { Total }(\mathrm{T})=101.242+55.133=156.375 \\
\Sigma T i^{2}=101.242^{2}+55.133^{2}=13.289 .590 .253 \\
\Sigma x i j^{2}=552.249 .188+171.153 .651=723.402 .839
\end{gathered}
$$

Where : $k=2 ; N=46$

$$
\begin{aligned}
& \text { And then: } k(N-1)=2(46-1)=90 \\
& \qquad \begin{array}{c}
N k-1=46(2)-1=91 \\
k-1=2-1=1
\end{array}
\end{aligned}
$$

\section{Correction (C)}

$$
C=\frac{T^{2}}{k . n}=\frac{156.375^{2}}{2 \times 46}=265.795 .006
$$


The sum of squares between sample (SSTr)

$$
S S T r=\left[\frac{\sum T i^{2}}{N}\right]-C=\left[\frac{13.289 .590 .253}{46}\right]-266.795 .006=22.109 .129
$$

\section{Sum of squares total (SST)}

$$
S S T=\sum x i j^{2}-C=334.272 .737 .897 .289 .000-265.795 .006=334.272 .737 .621 .493 .994
$$

\section{Sum of squares of error sample (SSE)}

$$
\begin{gathered}
S S E=S S T-S S T r=334.272 .737 .621 .493 .994-22.109 .129=334.272 .737 .599 .384 .865 \\
\text { TABLE 3: The Formula of Recapitulation analysis of variance. }
\end{gathered}
$$

\begin{tabular}{|l|c|c|c|c|}
\hline Variation & $\begin{array}{c}\text { Degrees of } \\
\text { dependent }\end{array}$ & $\begin{array}{c}\text { Sum of } \\
\text { squares }\end{array}$ & Mean of squares & RKf \\
\hline Treatment & $\mathrm{k}-1$ & $\mathrm{SSTr}$ & $\mathrm{Ms}(\mathrm{Tr})=\mathrm{SST} /(\mathrm{k}-1)$ & MSTr/MSE \\
\hline Error & $\mathrm{k}(\mathrm{N}-1)$ & $\mathrm{SSE}$ & $\mathrm{MSE}=\mathrm{SSE} / \mathrm{k}(\mathrm{n}-1)$ & \\
\hline Sum & $\mathrm{Nk}-1$ & $\mathrm{SST}$ & & \\
\hline
\end{tabular}

Then:

TABLE 4: Recapitulation analysis of variance.

\begin{tabular}{|l|c|c|}
\hline Variation & $\begin{array}{c}\text { Degrees of } \\
\text { dependent } \\
\text { df }\end{array}$ & Sum of squares \\
\hline Treatment & 1 & 22.109 .129 \\
\hline Error & 90 & 334.272 .737 .559 .384 .865 \\
\hline Sum & 91 & 334.272 .737 .621 .493 .994 \\
\hline
\end{tabular}

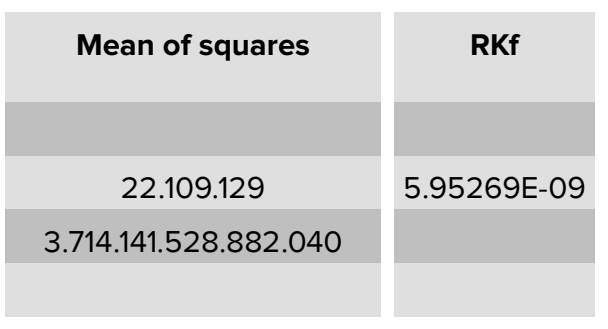

With see $\mathrm{F}$ table with probability $\alpha(5 \%)$, df-numerator $[(\mathrm{k}-1)=1]$ and df-denominator $[\mathrm{k}(\mathrm{N}-1)=90]$ with data from the limit value of the $\mathrm{F}$ distribution table is 3.95 ( $\mathrm{F}$ table) and $F$ arithmetic is 5.95269E-09. It means $F$ arithmetic $<F$ table so that, Ho accepted and sanitation have significant effect on diarrhea.

\section{Conclusions}

As discussed, this study proved that sanitation had a significant effect on diarrhea. In this study from table distribution $F$, we got $F$ table 3.95 with probability $\alpha(5 \%)$, df-numerator 
$[(\mathrm{k}-1)=1]$ and df-denominator $[\mathrm{k}(\mathrm{N}-1)=90]$ and $\mathrm{F}$ arithmetic is 5.95269E-09. It means $\mathrm{F}$ arithmetic $<\mathrm{F}$ table so that, Hypothesis nul $(\mathrm{Ho})$ accepted and sanitation have significant effect on diarrhea.

To solve the current problem, we must build the good sanitation management in the urban area. The government needs to build an integrated system with universal access for safe and hygienic water and sanitation in the urban area. If it can be realized, the public health status can be increased.

\section{References}

[1] Damanhuri E., Environmental Statistic, ITB, 2001.

[2] Dinas Kesehatan Provinsi Aceh Bidang Pelaporan. 2015. Profil Kesehatan Propinsi Aceh 2014.

[3] Percepatan Pembangunan Sanitasi Pemukiman (PPSP). 2015. Strategi Sanitasi Kabupaten. Kabupaten Pidie Provinsi Aceh.

[4] Shadish, R. W., Chook, D.T., Campbell, T.D. 2002. Experimental and QuasiExperimental Designs for Generalized Causal Inference. Houghton Mifflin Company. 33-63. 